Vol. 9(42), pp. 3156-3163, 16 October, 2014

DOI: $10.5897 / A J$ AR2013.7982

Article Number: 8BB9C 7448073

ISSN 1991-637X

Copyright (c) 2014

African Journal of Agricultural

Author(s) retain the copyright of this artic le

Research

http://www.academicjoumals.org/AJAR

\title{
Nitrogen application and inoculation with Rhizobium tropici on common bean in the fall/winter
}

\author{
Antonio Carlos Rebeschini ${ }^{1}$, Rita de Cássia Lima Mazzuchelli ${ }^{1}$, Ademir Sergio Ferreira de \\ Araujo $^{2}$ and Fabio Fernando de Araujo ${ }^{1^{*}}$ \\ ${ }^{1}$ UNOESTE, Agricultural Science Faculty , 19067-175, Presidente Prudente, SP, Brazil. \\ ${ }^{2}$ Federal University of Piauí, Agricultural Science Center, Teresina, PI, Brazil.
}

Received 26 September, 2013; Accepted 9 September, 2014

\begin{abstract}
The objective of this study was to evaluate doses of nitrogen in the cultivation of bean under field conditions, associated with seed inoculation. The study was conducted under field conditions in two traditional bean cultivation in Paraná northern (Cafeara and Florestopolis). The experiment consisted of plots with or without seed inoculation with Rhizobium tropici and use of five doses of nitrogen coverage $\left(0,20,40,60\right.$ and $\left.80 \mathrm{~kg} \mathrm{ha}^{-1}\right)$. Evaluations were made about the nodulation, $\mathrm{N}$ content in leaves, shoot dry matter, $\mathrm{N}$ uptake, number of pods per plant and grain yield. The experimental design was randomized blocks with ten treatments and four replicates. It was factorially arranged in five levels of nitrogen with and without inoculation. In this study there was no response to inoculation in the evaluation of the yield of bean in Cafeara and Florestopolis with different soil management. The nodulation of bean with Rhizobium is reduced by fertilization with mineral nitrogen. The system with tillage cultivation favored the development of bean during autumn-winter.
\end{abstract}

Key words: $\mathrm{N}_{2}$ fixation, Rhizobium spp., Phaseolus vulgaris.

\section{INTRODUCTION}

With an average yield of $951 \mathrm{~kg} \mathrm{ha}^{-1}$ in 2011 Brazil produced approximately 3.5 million tons of beans (IBGE, 2012). The cultivation of this legume is accomplished in three seasons, the first being called "rainy season", the second "the dry season" and the third "season of fall / winter." The small bean producers have invested frequently in the rainy season, due to the dependence on weather conditions, while large producers invest in other crops by the increased availability of irrigation (Person, 2012).

For production of protein-rich grain bean requires an adequate supply of nitrogen $(\mathrm{N})$, to care for their growth as well as for the formation of pods and grains (Fancelli and Dourado, 2007). The availability of mineral nitrogen for plants is directly dependent on the continuous decomposition of organic matter ( $\mathrm{N}$ mineralization), fertilization (Binotti et al., 2010) or biological $\mathrm{N}_{2}$ fixation (BNF) made by symbiotic association with rhizobia roots (Araújo et al., 2007). The need to improve productivity of legumes as a global source of dietary protein, however, has made it vital to understand the factors that influence nitrogen fixation (Schulze, 2004).

The efficiency of BNF in bean is very variable and under favorable environmental conditions can provide up 
Table 1. Analysis of soil composition of the experimental area of Cafeara and Florestopolis.

\begin{tabular}{llcc}
\hline Parameter & Units & Cafeara & Florestopolis \\
\hline $\mathrm{pH} \mathrm{CaCl}$ & & 4.9 & 5.0 \\
$\mathrm{pH}$ in SMP & & 6.4 & 6.8 \\
$\mathrm{Al}$ & & 0 & 0 \\
$\mathrm{Organic}$ matter & gmolc. $\mathrm{dm}^{-3}$ & 16.0 & 11.0 \\
$\mathrm{Ca}$ & $\mathrm{gmm}$ & 10.0 & 7.0 \\
$\mathrm{Mg}$ & $\mathrm{mmolc} \cdot \mathrm{dm}^{-3}$ & 4.0 & 3.0 \\
$\mathrm{~K}$ & $\mathrm{mmolc} . \mathrm{dm}^{-3}$ & 1.0 & 0.9 \\
$\mathrm{P}$ & $\mathrm{mmolc} \cdot \mathrm{dm}^{-3}$ & 2.0 & 11 \\
$\mathrm{SO}_{4}$ & $\mathrm{mg} \cdot \mathrm{dm}^{-3}$ & 8.9 & 6.2 \\
$\mathrm{Mn}$ & $\mathrm{mg} \cdot \mathrm{dm}^{-3}$ & 80.5 & 15.8 \\
$\mathrm{Fe}$ & $\mathrm{mg} \cdot \mathrm{dm}^{-3}$ & 31.9 & 15.1 \\
$\mathrm{Cu}$ & $\mathrm{mg} \cdot \mathrm{dm}^{-3}$ & 3.7 & 2.5 \\
$\mathrm{Zn}$ & $\mathrm{mg} \cdot \mathrm{dm}^{-3}$ & 6.9 & 1.2 \\
$\mathrm{~B}$ & $\mathrm{mg} \cdot \mathrm{dm}^{-3}$ & 0.32 & 0.29 \\
\hline
\end{tabular}

to $80 \mathrm{~kg}$ ha-1 of $\mathrm{N}$ fixed (Melo and Zilli, 2009). The application of $20 \mathrm{~kg} \mathrm{ha}^{-1}$ of nitrogen at seeding associated with rhizobia inoculation can provide input of $160 \mathrm{~kg} \mathrm{ha}^{-1}$ nitrogen (Pelegrin et al., 2009). It is necessary to care for the dose of $\mathrm{N}$ at sowing as studies have documented the negative impact of high nitrate concentration in soil on nodulation and nodule weight (Muller and Pereira, 1995).

The species of Rhizobium with higher prevalence in symbiosis with bean show frequencies of $17,1 \%$ at Rhizobium tropici, 35.9\% Rhizobium etli, 32.5\% Rhizobium leguminosarum, 1.7\% Rhizobium giardinii and $12.8 \%$ with distinct profiles of described species of bean rhizobia, emphasizing the high genetic diversity of rhizobia, including the appointment of new species (Stocco et al., 2008).

The lack of response to inoculation of bean is usually due to the inability of strains inoculated to compete with native species for soil infection sites in roots (Ferreira et al., 2011). The bean can respond similarly with and without inoculation, indicating soils with high native communities of rhizobia in the soil (Pelegrin et al., 2009). There is a variability in responses to both bean rhizobial inoculation and to nitrogen fertilization, mainly influenced by the levels of soil fertility and other techniques used in production systems, especially the use of irrigated systems (Pelegrin et al., 2009). The efficiency of nitrogen absorption is enhanced in these cultivation systems, with this reducing production costs (Sant'ana et al., 2011).

In many regions of the world where common beans are grown, nitrogen fixation is limited by unfavorable soil conditions and temperature and water stress (Kabahuma, 2013). The tilling season and soil management contribute decisively to obtain high yields in dry beans. Bean plants grown in no-tillage has provided better conditions for nitrogen use, possibly because of increased soil water retention which may buffer temperature (Romanini Junior et al., 2007). In this context the hypothesis of this study is that the climatic conditions and soil water availability, found in the growing season of the third season (autumnwinter), are crucial for the evaluation of BNF. This work aimed at the effect of rhizobia inoculation and application of nitrogen in cover on bean cultivation in two distinct areas, the autumn-winter season.

\section{MATERIALS AND METHODS}

\section{Experimental site}

The study was conducted in two areas of traditional cultivation of bean in northern Paraná, Brazil in 2010. One area is located at Cafeara (22 $\left.46^{\prime} 22^{\prime \prime} \mathrm{S} ; 51^{\circ} 43^{\prime} 18^{\prime \prime} \mathrm{W}\right)$ altitude of $377 \mathrm{~m}$. The other at Florestopolis ( $22^{\circ} 52^{\prime} 25^{\prime \prime} \mathrm{S}$; $\left.51^{\circ} 22^{\prime} 55^{\prime \prime} \mathrm{W}\right)$ altitude $400 \mathrm{~m}$. The soil in both areas is classified as ultisol, emphasizing that the soil Cafeara is under no-tillage (NT). The soil fertility analysis are presented in Table 1. The experiment was conducted in the fall / winter season, from April to August 2010.

\section{Biological material}

In the experiment was used bean genotype Carioca (IPR 139), indeterminate growth. The inoculum used in the study was commercial inoculant in peat formulation (Turfal, Curitiba, PR) containing $R$. tropici, strain SEMIA 4088, the concentration of $1.0 \times$ $10^{9}$ viable cells per gram of product. The dosage used was that recommended by the manufacturer of $100 \mathrm{~g}$ per $50 \mathrm{~kg}$ of seed. The product was added to seeds with use of sugar adhesive solution plus $10 \%$ (weight) immediately prior to sowing.

\section{Experimental design}

The experiment consisted of plots with or without inoculation of $R$. tropici seeds and use of five $\mathrm{N}$ rates $\left(0,20,40,60\right.$ and $\left.80 \mathrm{~kg} \mathrm{ha}^{-1}\right)$ in cover effected at 20 and 40 days after plant emergency. A completely randomized block with ten treatments arranged factorially with four replications was used. The experimental unit consisted of plots with six bean lines $(5 \mathrm{~m})$ spaced at $0.45 \mathrm{~m}$ 


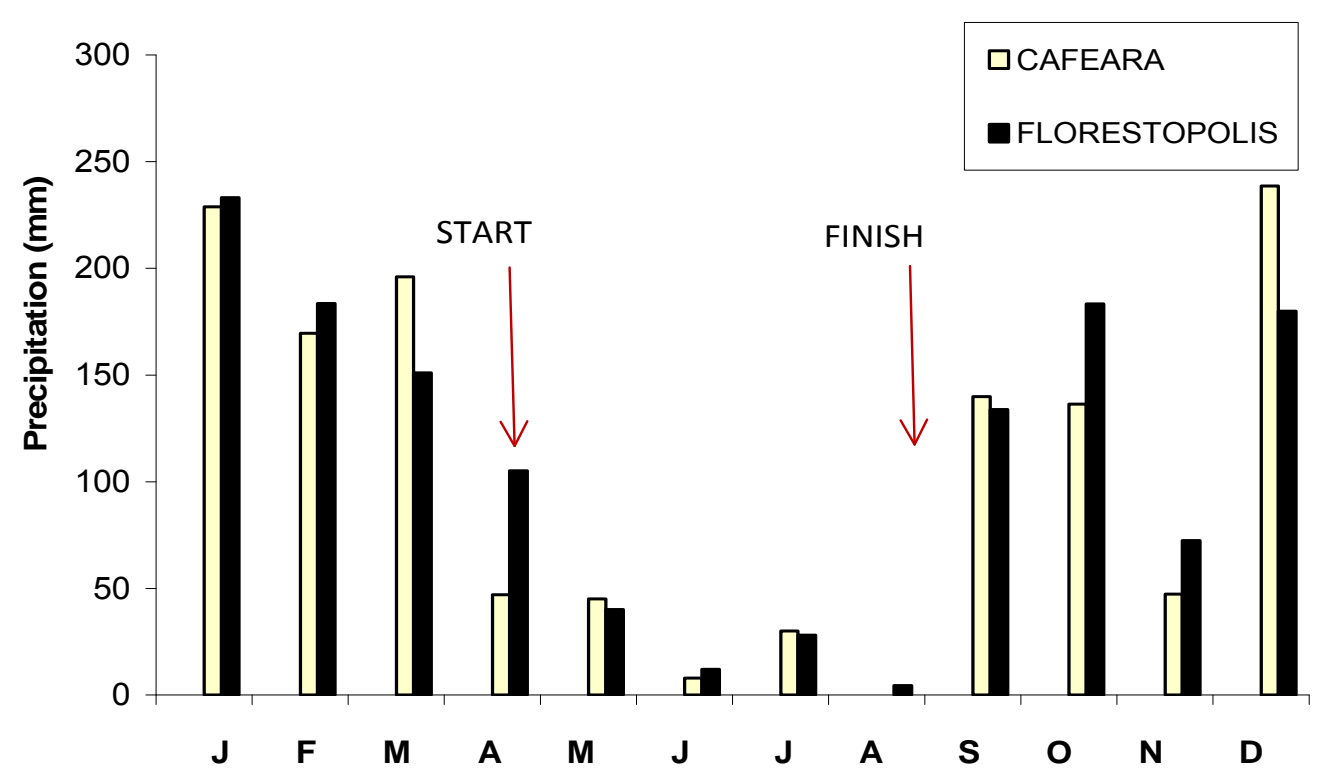

Figure 1. Rainfall accumulation in 2010 in the experimental areas in Cafeara and Florestopolis.

between rows and a total area of $13.5 \mathrm{~m}^{2}$ per plot.

\section{Cultivation}

The plants was conducted in the field under natural conditions of climate and soil. Based on the analysis of soil fertility was effective at sowing fertilization with $250 \mathrm{~kg} \mathrm{ha}^{-1}$ of NPK fertilizer $(00-20-20)$, and afterwards we made fertilization coverage with urea $(45 \% \mathrm{~N})$ according to pre-established treatments. The seeds were sown in April. The production system and plant management such as control of pests, diseases and weeds were conducted in accordance with the detected events and technical recommendations for culture in the region.

\section{Number and weight of nodules, foliar $\mathrm{N}$ and biomass}

For evaluation of nodulation and dry matter of the plant were collected 10 plants per plot at the stage of full flowering (R6). To determine concentration of nitrogen leaves were collected from the middle third of 30 plants per plot. To count the number of pods per plant were collected ten plants per plot at maturity stage (R9). The analysis and quantification of shoot dry weight and dry weight of nodules were performed in the laboratory after drying the material on forced ventilation oven $\left(60-70^{\circ} \mathrm{C}\right)$ to constant weight. The analysis of leaf total $\mathrm{N}$ were performed according to methodology (Malavolta et al., 1997).

\section{Evaluation of yield}

For the determination of final yield, the plants were collected from two central rows of each plot, ignoring $0.5 \mathrm{~m}$ of each line at the beginning and end, that after threshing and grain moisture correction to $13 \%$ was calculated grain yield per hectare.

\section{Statistical analysis}

The data were subjected to analysis of variance (ANOVA) by F test
$(\mathrm{P} \leq 0.05$ and $\mathrm{P} \leq 0.01)$ and when found statistical differences were applied to regression analysis doses nitrogen using the statistical software SISVAR (Ferreira, 2000).

\section{RESULTS AND DISCUSSION}

Climatic conditions, monitored here as water availability during the experiment period (Figure 1), showed in Cafeara precipitation total of $140 \mathrm{~mm}$, below the crop necessity because there are reports that at 75 days cycle development bean has one evapotranspiration $220 \mathrm{~mm}$ (Silveira and Stone, 1979). In Florestopolis, there was total precipitation of $108 \mathrm{~mm}$. With respect to temperature variation in both locations, there were minimum temperature of $12^{\circ} \mathrm{C}$ and maximum $25^{\circ} \mathrm{C}$, during the period of the experiment.

With respect to use of inoculant only in the number of pods in Cafeara experiment showed positive effect with $\mathrm{P}<0.01$ (Table 2), no significant response was obtained in the experiment Florestopolis (Table 3). Souza et al. (2011) also found that seed inoculation only increased the number of pods per plant in the absence of $\mathrm{N}$. Was found significative $F$ values in most parameters in the analysis of the effect of $\mathrm{N}$ rates. The bean yield ranged

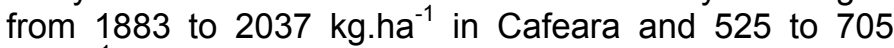
$\mathrm{kg} \cdot \mathrm{ha}^{-1}$ Florestopolis. The values obtained in Cafeara were well above the average of $951 \mathrm{~kg}^{-h^{-1}}$ in Brazil and $705 \mathrm{~kg} \cdot \mathrm{ha}^{-1}$ in the Paraná State (Conab, 2011).

There was a decrease in nodulation on the roots of bean, with regression adjusted a linear $(P<0.05)$, when increase the dose of mineral nitrogen in Cafeara (Figure 2A). In Florestopolis no significant adjustment for nodulation between treatments with doses of $\mathrm{N}$, in the absence and presence of inoculation (Figure 2B). In 
Table 2. Mean values of nodulation, pod number, plant dry matter, leaf $\mathrm{N}$ and yield of beans in doses of inoculant and nitrogen. Cafeara PR.

\begin{tabular}{|c|c|c|c|c|c|}
\hline Treatments & Nodulation (number plant ${ }^{-1}$ ) & $\begin{array}{l}\text { Nodules weigth } \\
\text { (mg.plant }^{-1} \text { ) }\end{array}$ & $\begin{array}{c}\mathrm{N}^{\circ} \text { of pods } \\
\text { per plant }\end{array}$ & $\mathrm{N}$ foliar $\left(\mathbf{g} \cdot \mathbf{k g}^{-1}\right)$ & Yield (kg.ha $\left.{ }^{-1}\right)$ \\
\hline \multicolumn{6}{|l|}{ Inoculation } \\
\hline Yes & 20.6 & 43.4 & 9.32 & 37.5 & 1996.9 \\
\hline No & 24.4 & 53.1 & 8.38 & 36.9 & 1983.8 \\
\hline $\mathrm{F}$ & 3.09 & 3.64 & $7.59^{* \star}$ & 0.65 & 0.073 \\
\hline \multicolumn{6}{|c|}{$\mathrm{N}$ doses $\left(\mathrm{Kg}_{\mathrm{K}} \cdot \mathrm{ha}^{-1}\right)$} \\
\hline 0 & $33.7^{\mathrm{a}}$ & $57.6^{\mathrm{ab}}$ & $7.46^{c}$ & $34.9^{b}$ & 1932 \\
\hline 20 & $25.5^{\mathrm{ab}}$ & $63.2^{a}$ & $8.45^{\mathrm{bc}}$ & $36.7^{\mathrm{ab}}$ & 2001 \\
\hline 40 & $19.6^{b}$ & $46.2^{\mathrm{ab}}$ & $8.91^{\mathrm{abc}}$ & $37.0^{\mathrm{ab}}$ & 1949 \\
\hline 60 & $16.2^{b}$ & $35.3^{b}$ & $9.03^{a b}$ & $38.1^{\mathrm{ab}}$ & 2046 \\
\hline 80 & $17.4^{\mathrm{b}}$ & $38.9^{b}$ & $10.4^{\mathrm{a}}$ & $39.2^{\mathrm{a}}$ & 2021 \\
\hline $\mathrm{F}$ & $9.13^{\star *}$ & $4.43^{\star *}$ & $7.86^{\star *}$ & $3.61^{*}$ & 0.79 \\
\hline CV & 30.6 & 33.1 & 8.85 & 6.42 & 7.66 \\
\hline
\end{tabular}

* and ${ }^{* *}$ significant at the $5 \%$ and $1 \%$ probability according to the $\mathrm{F}$ test.

Table 3. Mean values of nodulation, pod number, plant dry matter, leaf $\mathrm{N}$ and yield of beans in doses of inoculant and nitrogen. Florestopolis - PR.

\begin{tabular}{|c|c|c|c|c|c|}
\hline Treatments & $\begin{array}{c}\text { Nodulation } \\
\left.\text { (number plant }^{-1}\right)\end{array}$ & $\begin{array}{l}\text { Nodules weigth } \\
\text { (mg.plant }^{-1} \text { ) }\end{array}$ & $\begin{array}{l}\mathrm{N}^{\circ} \text { of pods } \\
\text { per plant }\end{array}$ & $\mathrm{N}$ foliar $\left(\mathrm{g} \cdot \mathrm{Kg}^{-1}\right)$ & Yield $\left(\mathrm{Kg} \cdot \mathrm{ha}^{-1}\right)$ \\
\hline \multicolumn{6}{|l|}{ Inoculation } \\
\hline Yes & 36.9 & 45.8 & 3.50 & 37.1 & 612 \\
\hline No & 30.3 & 44.7 & 3.78 & 37.6 & 624 \\
\hline $\mathrm{F}$ & 2.24 & 0.011 & 1.05 & 1.53 & 0.185 \\
\hline \multicolumn{6}{|c|}{$\mathrm{N}$ doses $\left(\mathrm{Kg} \cdot \mathrm{ha}^{-1}\right)$} \\
\hline 0 & 46.3 & $79.4^{a}$ & 3.21 & $37.2^{a b}$ & $509^{b}$ \\
\hline 20 & 26.6 & $43.2^{b}$ & 3.68 & $36.5^{b}$ & $642^{a}$ \\
\hline 40 & 34.3 & $34.9^{b}$ & 3.58 & $36.5^{b}$ & $658^{a}$ \\
\hline 60 & 33.9 & $38.4^{b}$ & 4.01 & $38.1^{a}$ & $656^{a}$ \\
\hline 80 & 26.9 & $29.2^{b}$ & 3.71 & $38.6^{a}$ & $624^{\mathrm{ab}}$ \\
\hline $\mathrm{F}$ & 2.54 & $7.34^{\star \star}$ & 0.85 & $3.75^{\star}$ & \\
\hline $\mathrm{CV}$ & 42.1 & 46.4 & 24.3 & 3.65 & 14.1 \\
\hline
\end{tabular}

${ }^{*}$ and ${ }^{* *}$ significant at the $5 \%$ and $1 \%$ probability according to the $\mathrm{F}$ test.

general, there was good nodulation of bean plants in the absence of inoculation, in two locations measured.

Pelegrin et al. (2009) observed that nodulation in bean plants that were not inoculated was similar to inoculated, mainly due to population of native rhizobia in the soil. Similarly, Hungria et al. (2003) observed no significant differences in the number of nodules of bean plants inoculated with rhizobia and that received $\mathrm{N}$ fertilization (30 kg ha-1 at sowing $+30 \mathrm{~kg} \mathrm{ha}^{-1}$ in coverage) when comparing nodulation provided by the native population soil. The inhibitory effect of $\mathrm{N}$ on nodulation is probably plant mediated; however, differences in tolerance to nitrate and ammonium have also been found between rhizobial isolates when investigated in nodulated systems
(Nelsen, 1987).

There was significant adjustment $(P<0.05)$ for increasing the number of pods when increased doses of $N$ and inoculated with Rhizobium in Cafeara (Figure 3A). In Florestopolis the adjustment quadratic was significant $(P$ $<0.05$ ) for doses of $\mathrm{N}$ without inoculation (Figure $3 \mathrm{~B}$ ). In the analysis of the dry mass of the shoot, there was a significant adjustment quadratic $(P<0.05)$ with increased dry matter at the highest levels of mineral $\mathrm{N}$ in uninoculated treatments in Cafeara experiment (Figure 4). In Florestopolis the regression analysis was significant $(P$ $<0.01$ ), showing maximum production at the dose of 40 $\mathrm{kg} \mathrm{N}$ per hectare, when using inoculation. Responses of bean to nitrogen fertilization have been variable in dry 

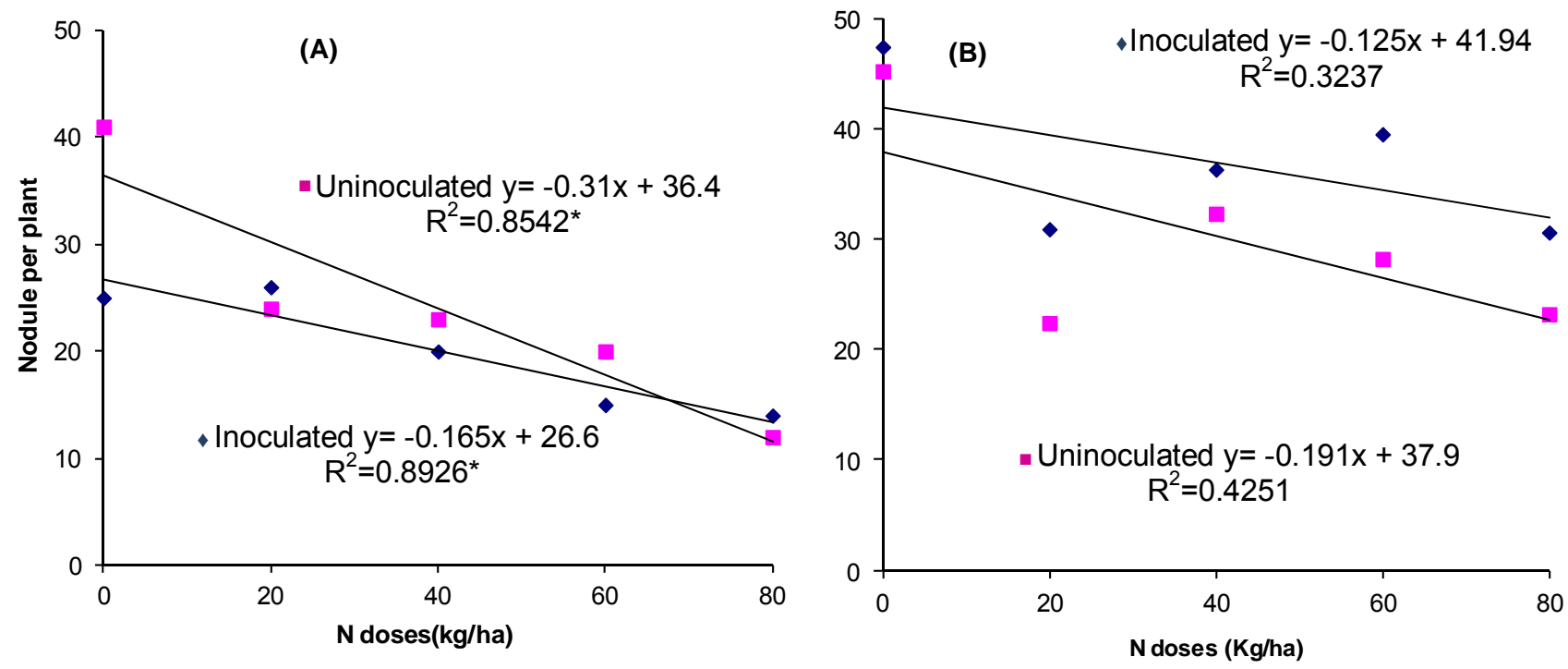

Figure 2. Nodulation after inoculation of bean seeds and applied dosages of nitrogen in (A) Cafeara and (B) Florestopolis. * significant differences $(\mathrm{P}<0.05)$.
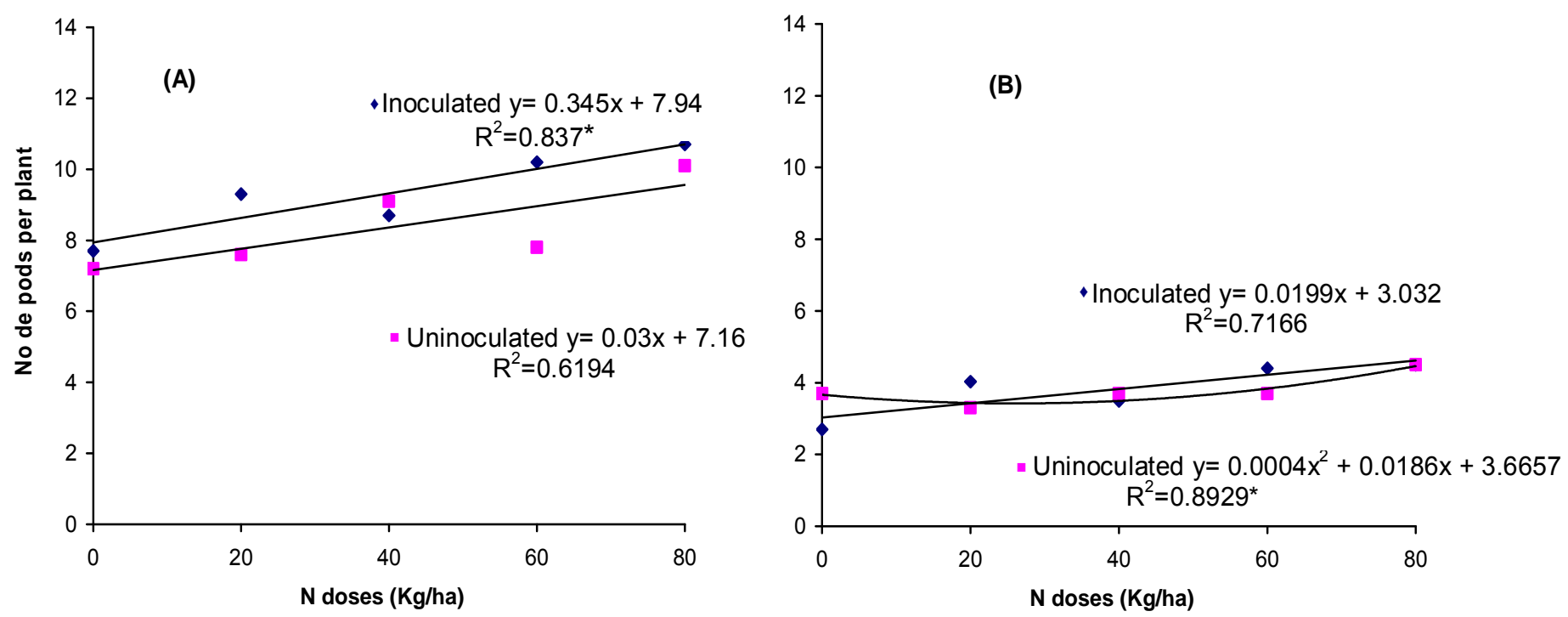

Figure 3. Number of pods after inoculation in bean seed and applied dosages of nitrogen in(A) Cafeara (B) Florestopolis. ${ }^{*}$ significant differences $(P<0.05)$.

matter production, observed positive effects (Carvalho et al., 2001) or no significant effects (Soratto et al., 2006). In Cafeara there was increase in the leaf $\mathrm{N}$ content, with significant linear adjustment for both the inoculated treatments $(P<0.01)$ and for those without inoculation $(P<0.05)$ (Figure 5A). Quadratic adujstment was found to be significant $(P<0.05)$ for doses of mineral $N$ without inoculation in Florestopolis (Figure 5B).

In all the treatments the foliar $\mathrm{N}$ content was observed to be below critical level for the plants, $30 \mathrm{~g}$ de $\mathrm{N} \mathrm{kg}^{-1}$, in accord with Ambrosano et al. (1997), or 30 to $50 \mathrm{~g}$ de N $\mathrm{kg}^{-1}$ (Malavolta et al., 1997). These levels are found in beans under conditions of fertility soil or native communities of rhizobia with high efficiency (Soratto et al., 2006; Farinelli et al., 2006). In conditions of poor soils in $\mathrm{N}$ (with low organic matter) and low populations of rhizobia symbiotically efficient the application of mineral nitrogen has provided higher foliar $\mathrm{N}$ than those in plants without fertilization (Carvalho et al., 2001).

Maximum values of nitrogen accumulation were found around 100 and $30 \mathrm{~kg}$ of $\mathrm{N}$ per ha, in Cafeara and Florestopolis respectively. In Brazil the average rates of BNF contribution to the beans are of the order of $60 \mathrm{~kg} \mathrm{~N}$ per hectare and represent 30 to $50 \%$ of total $\mathrm{N}$ 

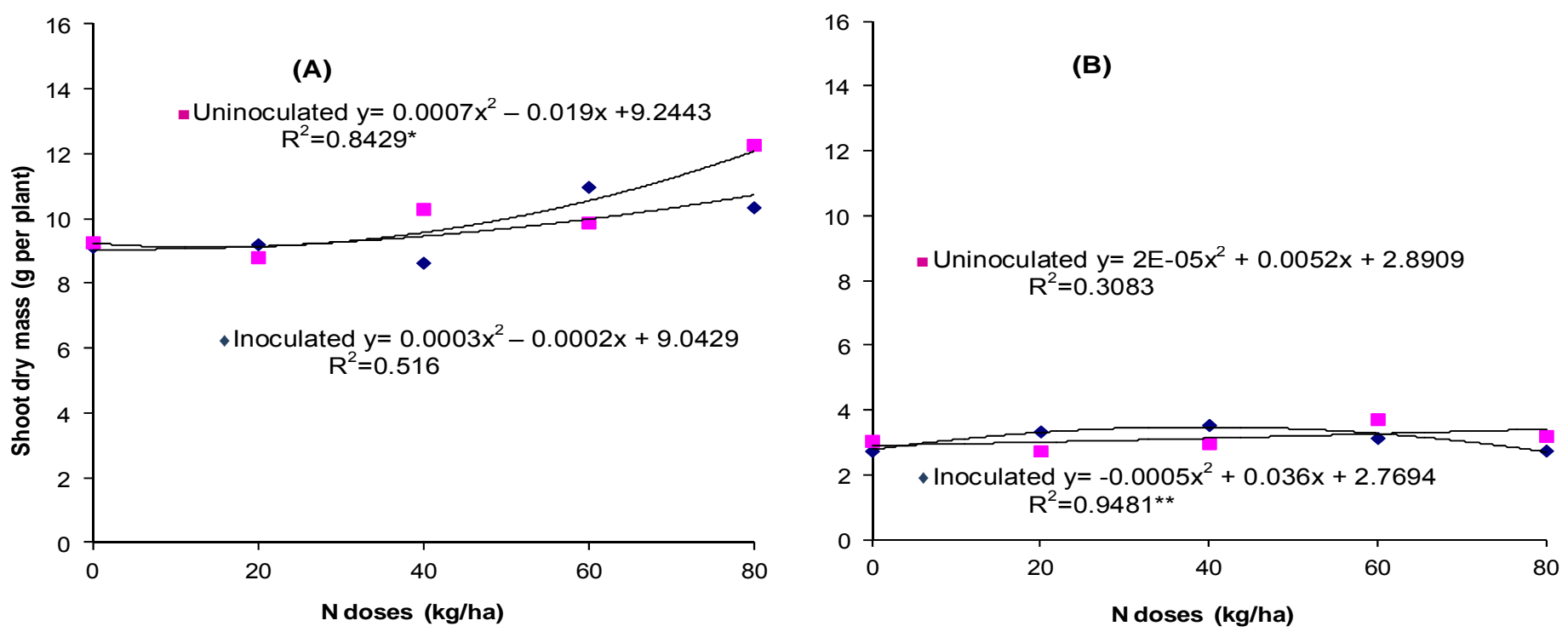

Figure 4. Dry mass of shoots in bean seed inoculation and after applied dosages of nitrogen in (A) Cafeara and (B) Florestopolis. * and ${ }^{* *}$ significant differences $(P<0.05)$ and $(P<0.01)$.
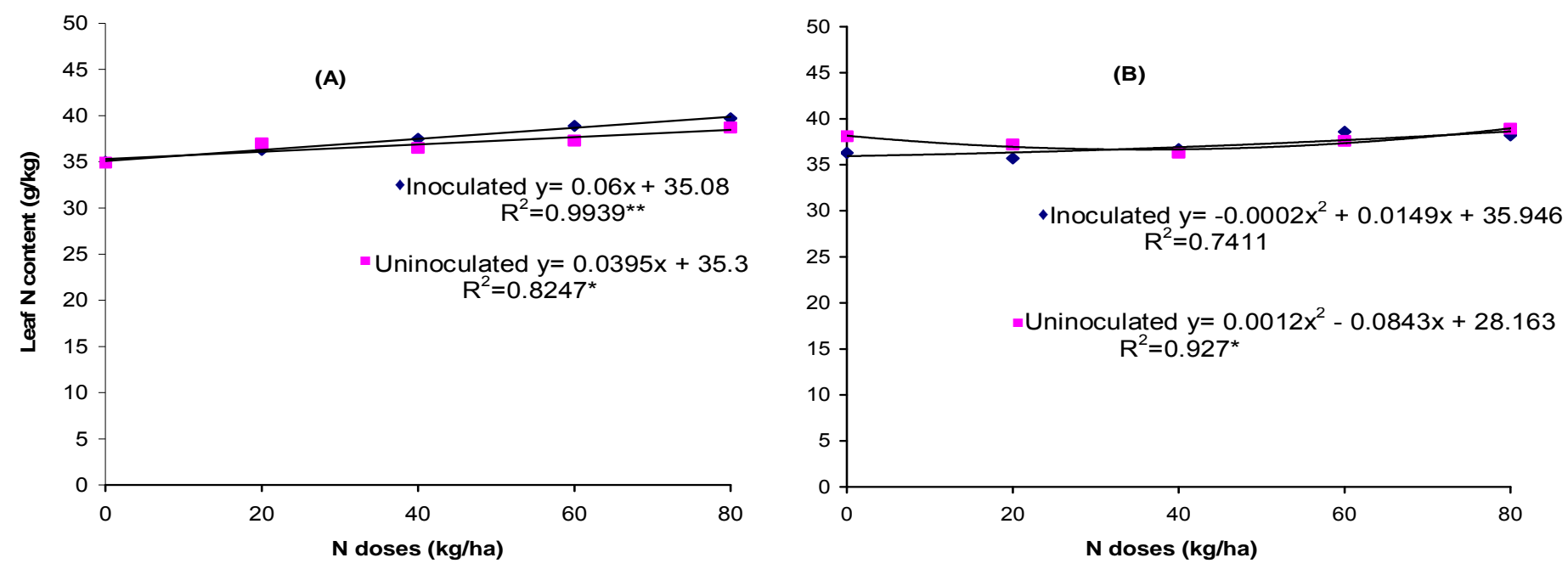

Figure 5. Leaf $\mathrm{N}$ content in bean seed inoculation and after applied dosages of nitrogen in (A) Cafeara and (B) Florestopolis. * and ** significant differences $(P<0.05)$ and $(P<0.01)$.

accumulated by the plant (Pelegrin et al., 2009). Moura et al. (2009) concluded that the species of native soil rhizobia are as efficient as the inoculation of $R$. tropici in supplying $\mathrm{N}$ to the bean. The responses to nitrogen fertilization in grain production also has generated much controversy, about that Souza et al. (2011) found that yield of bean is little influenced by nitrogen fertilization. Soratto et al. (2006), in studies conducted in Brazilian Midwest, found significant responses for yield of bean, with the estimated dose for maximum response of bean in $140 \mathrm{~kg} \mathrm{ha}^{-1} \mathrm{~N}$. Farinelli et al. (2006), in Brazilian southeast, evaluated the application of $\mathrm{N}$ in bean crops under no tillage and conventional tillage and found the maximum yield with the application of $185 \mathrm{~kg} \mathrm{~N}$ per hectare. There has been variability in responses in productivity to levels of mineral $\mathrm{N}$, mainly influenced by the levels of soil fertility and other techniques used in production systems, especially the use of irrigation systems (Pelegrin et al., 2009).

Concerning the performance of bean production in both locations, it was observed that the experiment of Cafeara had a good grain yield, indicating that this area is two 
years in no tillage. Soratto et al. (2006) also found increased yield of common bean in no-tillage, with inoculation and application of $\mathrm{N}$ in coverage. In Florestopolis showed low organic matter content in the soil (Table 1) and conventional soil management may have contributed to reduction in crop development especially in conditions of water stress, which may have been decisive for the low yield of bean.

The bean yield is affected by soil water availability. A deficiency of water in soil can reduce productivity in different proportions according to the different phases of the cycle, especially during flowering and early pod formation (Fancelli and Dourado, 2007).

Under the conditions of this study it was found adequate nodulation of bean and no response to inoculation of bean and supply of mineral $\mathrm{N}$ in two different situations, differentiated mainly by soil management. It was observed that the condition of the experiment Cafeara where good crop yield, factors $\mathrm{N}$ dose or inoculation was found was not used in determining this result. In this condition it can be suggested that the $\mathrm{N}$ mineralization of organic matter and FBN due to the presence of rhizobia provided greater supply of $\mathrm{N}$ to the bean. A favorable environment in the rhizosphere is vital to interaction legume-rhizobium; however, the magnitude of the stress effects and rate of inhibition of the symbiosis usually depend on the phase of growth and development, as well as the severity of the stress. For example, mild water stress reduces only the number of nodules formed on roots of soybean, while moderate and severe water stress reduces both the number and size of nodules (Williams and De Mallorca, 1984). Other factors are also related to the failure of inoculations as the competitiveness and efficiency of strains of Rhizobium inoculant and also by the response of bean genotype used.

\section{Conclusions}

In this study there was no response to inoculation in the evaluation of the yield of bean in Cafeara and Florestopolis with different soil management. The nodulation of bean with Rhizobium is reduced by fertilization with mineral nitrogen. The system with tillage cultivation favored the development of bean during autumn-winter.

\section{Conflict of Interest}

The authors have not declared any conflict of interest.

\section{REFERENCES}

Ambrosano EJ, Tanaka RT, Mascarenhas HAA, Raij BVan, Quaggio JA, Cantarella H (1997). Leguminosas e oleaginosas. In: Raij BVan,
Cantarela H, Quaggio JA, Furlani AMC, eds. Recomendações de adubação e calagem para o Estado de São Paulo. Campinas, Instituto Agronômico de Campinas 187:203.

Araújo FF, Carmona FG, Tiritan CS, Creste JE (2007). Fixação biológica de N2 no feijoeiro submetido a dosagens de inoculante e tratamento químico na semente comparado à adubação nitrogenada. Acta Sci. Agron. 29(4):535-540.

Binotti FFS, ARF O, Cardoso ED, Sá ME, Buzetti S, Nascimento V (2010). Fontes e doses de nitrogênio em cobertura no feijoeiro de inverno irrigado no sistema plantio direto. Biosci. J. Uberlândia 26(5):770-778

Carvalho MAC, Furlani EJ, Arf O, Sá ME, Paulino H, Buzetti S (2001). Produtividade e qualidade de sementes de feijoeiro (Phaseolus vulgaris L.) sob influência de parcelamentos e fontes de nitrogênio. Rev. Bras. Ciência do Solo 25(6):617-624.

Conab-Companhia Nacional de Abastecimento - prospecção safra 2011-2012. Conab feijão- Acesso em 21 mai 2012. www.conab.br

Farinelli R, Lemos LB, Penariol FG, Egéa MM, Gasparoto MG (2006). Adubação nitrogenada de cobertura no feijoeiro, em plantio direto e convencional. Pesquisa Agropecuária Bras. 41(3):307-312. http://dx.doi.org/10.1590/S0100-204X2006000200016

Fancelli AL, Dourado Neto D (2007). Produção de Feijão. Piracicaba: ESALQ/USP, Departamento de Agricultura P. 386.

Ferreira EPB, Martins LMV, Xavier GR, Rumjanek NG (2011). Nodulação e produção de grãos em feijão-caupi (Vigna unguiculata L. Walp.) inoculado com isolados de rizóbio. Rev. Caatinga Mossoró 24(4):27-35.

Ferreira DF (2000) Variance analysis system for balanced date. Lavras: UFLA.

Hungria M, Campo RJ, Mendes I (2003). Benefits of inoculation of the common bean (Phaseolus vulgaris) crop with efficient and competitive Rhizobium tropici strains. Biol. Fertil. Soils 39(2):88-93. http://dx.doi.org/10.1007/s00374-003-0682-6

Kabahuma MK (2013) Enhancing biological nitrogen fixation in common bean (Phaseolus vulgaris L). Graduate Theses and Dissertations. P. 13162.

Malavolta E, Vitti GC, Oliveira AS (1997). Avaliação do estado nutricional das plantas: princípios e aplicações. 2. ed. Piracicaba: Potafos P. 319.

Melo SR, Zilli JE (2009). Fixação biológica de nitrogênio em cultivares de feijão-caupi recomendadas para o Estado de Roraima. Pesquisa agropecuária Bras. 44(9):1177-1183.

Moura JB, Guareschi RF, Correia AR, Gasolla AF (2009). Produtividade do feijoeiro submetido à adubação nitrogenada e inoculação com Rhizobium tropici. Global Sci. Technol, 2(3):66-71.

Muller SH, Pereira PAA (1995). Nitrogen fixation of common bean (Phaseolus vulgaris L.) as affected by mineral nitrogen supply at different growth stages. Plant Soil 177:55-61. http://dx.doi.org/10.1007/BF00010337

Pelegrin R, Mercante FM, Otsubo IMN, Otsubo AA (2009). Resposta da cultura do feijoeiro à adubação nitrogenada e à inoculação com rizóbio. Rev. Bras. de Ciência do Solo, 33(1):219-226. http://dx.doi.org/10.1590/S0100-06832009000100023

Nelsen LM (1987). Response of Rhizobium leguminosarum isolates to different forms of inorganic nitrogen during nodule development in pea (Pisum sativum L.). Soil Biol. Biochem. 19:759-763. http://dx.doi.org/10.1016/0038-0717(87)90060-5

Romanini Júnior A, Arf O, Binotti FFS, Sá ME, Buzetti S, Fernandes FA (2007). Avaliação da inoculação de rizóbio e adubação nitrogenada no desenvolvimento do feijoeiro, sob sistema plantio direto. Biosci. J. 23(4):74-82.

Sant'ana EVP, Santos AB, Silveira PM (2011). The efficiency of use of nitrogen applied in top dressing in irrigated beans. Revista Brasileira de Engenharia Agrícola e Ambiental 15(5):458-462.

Schulze J (2004). How are nitrogen fixation rates regulated in legumes? Plant Nutr. Soil Sci. 167:125-137.

Silveira PM, Stone LF (1979). Balanço de água na cultura do feijão em Latossolo Vermelho Amarelo. Pesquisa Agropecuária Bras. 14:111116.

Soratto RP, Carvalho MAC, Arf O (2006). Fertilidade do solo e nutrição de plantas. Rev. Bras. de Ciência do Solo. 30(1):259-265. http://dx.doi.org/10.1590/S0100-06832006000200007 
Souza EFC, Soratto RP, Pagani FA (2011). Aplicação de nitrogênio e inoculação com rizóbio em feijoeiro cultivado após milho consorciado com braquiaria, Pesquisa Agropecuária Bras. 46(4):370-377. http://dx.doi.org/10.1590/S0100-204X2011000400005

Stocco P; Santos JCP, Vargas VP, Hungria M (2008). Avaliação da biodiversidade de Rizóbios simbiontes do feijoeiro (Phaseolus vulgaris L.) em Santa Catarina. Rev. Bras. de Ciencia do Solo. 32(3):1107-1120. http://dx.doi.org/10.1590/S0100-06832008000300019

Williams PM, De Mallorca MS (1984) Effect of osmotically induced leaf moisture stress on nodulation and nitrogenase activity of Glycine max. Plant Soil 80:267-283.

http://dx.doi.org/10.1007/BF02161183 